\title{
ENVIRONMENTAL RIGHTS IN ETHIOPIA: SHIFTING FROM THEORY TO PRACTICAL REALIZATION
}

\author{
Desalegn Amsalu*
}

\begin{abstract}
Influenced by developments in the international environmental rights law, most African countries now incorporate in their Constitutions or other major legal documents environmental rights for their citizens. The 1995 Federal Constitution of Ethiopia, its environmental policy, and all subsequent legislation also incorporate environmental rights that are in the major international environmental law conventions. These rights include the right to a clean and healthy environment, the right to access justice, as well as the right to information and public participation. However, the environmental rights that are included in the country's Constitution, policies and laws are simply rhetorical. For example, in Addis Ababa, the country's capital, residents suffer from such horrendous odour oozing out of the putrefaction of the environment. Consequently, children and even adults are affected by various diseases such as respiratory and skin infections. Some residents even abandon their homes, not being able to resist the pollution of their environment. The government's lack of human resource capacity and appropriate technology to promote a healthy and safe environment; its preference of economic growth over environmental protection; environmental corruption; and poor responsiveness of the public, the policy makers, the executive, as well as the judicial organs such as the police and the court to environmental rights, are among the major causes of poor implementation. The article examines how environmental rights could be given due attention as an extension of basic human rights and as a tool for sustainable economic development.
\end{abstract}

Keywords: Environmental rights, theory, practice, factors for poor enforcement, Ethiopia.

DOI: https://dx.doi.org/10.4314/jsdlp.v9i2.4

* Desalegn Amsalu LLB (Hons), MA, and PhD (Addis Ababa University), currently legal researcher at Addis Ababa University, Ethiopia. Email: desalegn.amsalu@aau.edu.et. This work is done based on funding from Addis Ababa University under a thematic research award from 2014-2016. Any opinion, finding and conclusion or recommendation expressed in this article is that of the author only. 


\section{INTRODUCTION}

Influenced by international developments like many other African states, the Ethiopian environmental law contains robust references to the fulfilment and attainment of environmental rights to the people of Ethiopia. However, despite the robust theoretical recognition of environmental rights in Ethiopian law, not much has been realized in practice. The purpose of this article is to investigate legal pathways for the practical realization and enforcement of environmental rights in the country and approaches for addressing the factors responsible for poor implementation.

Since the nineteenth century, several attempts have been made to lay down international environmental law instruments to address global environmental crises. The earliest attempts, however, focused on the conservation of the wildlife. ${ }^{1}$ It was not until the United Nations Conference on the Human Environment in Stockholm, 5-16 June 1972 (the Stockholm Conference for short) that environmental rights, particularly, the right to a healthy environment was explicitly recognized in an international environmental instrument for the first time. The Stockholm Conference resulted in the Stockholm Declaration, composed of three non-binding instruments: a resolution on financial and institutional arrangements, a declaration consisting of 26 principles, and an action plan containing 109 recommendations. Principle 1 of the Declaration linked environmental protection to human rights norms.

The Stockholm Declaration was to influence the legal and institutional development of nations for the next two decades. ${ }^{2}$ It also influenced the creation of the United Nations Environment Program (UNEP) in the same year the Stockholm Declaration was adopted. ${ }^{3}$ The

1 See, for example, The Bonn Agreement which is the 1969 European environmental agreement to ensure mutual cooperation in the avoidance and combating of environmental pollution; CITES (the 1963 Convention on International Trade in Endangered Species of Wild Fauna and Flora, also known as the Washington Convention) to protect endangered plants and animals; and The 1969 International Convention Relating to Intervention on the High Seas in Cases of Oil Pollution Casualties.

2 G Handl "Declaration of the United Nations Conference on the Human Environment (Stockholm Declaration), 1972" and "The Rio Declaration on Environment and Development, 1992" (2012).

3 D Worster "The Vulnerable Earth: Towards a Planetary History" in D Worster (ed.) The Ends of the Earth (1988)3. 
Stockholm conference was the most successful of international conferences at the time, successful both in terms of the organization of the conference and the outcome. ${ }^{4}$

Twenty years after the Stockholm Declaration, on 3"14 June 1992, the UN Conference on Environment and De-velopment (UNCED) (the Rio Conference, for short) was held in Rio de Ja-neiro, Brazil. The purpose of the conference was to elaborate strate-gies and measures to halt and reverse the effects of environmental degra-dation and to strengthen national and international efforts to promote sus-tainable and environmentally sound development in all countries. The Rio Conference had extraordinary participation from thou-sands of nongovernmental organizations from around the world. ${ }^{5}$ The Conference also adopted three non-binding instruments, one of which was the Rio Declaration which identified 27 principles. Principle 1 of the Rio Declaration states that human beings are "at the centre of concerns for sustainable development. They are entitled to a healthy and productive life in harmony with nature." ${ }^{\prime 6}$ While this declaration fell short of recognizing a healthy environment as a basic human right, Principle 1 points into that direction.

The Stockholm and the Rio Declarations stimulated a number of regional and national developments in recognition of environmental right as a human right. Following this development, many national constitutions and laws have recognized the right to a healthy environment derived from the obligation of states to adopt the principles reflected in the two declarations. ${ }^{7}$

Influenced by these international developments, the African constitutions have made so much progress in recognizing environmental rights as human rights. The 1981 African Charter on Human and People's Rights under article 24 included environmental rights as part of human rights, and Africa as a whole thus became the first continent to introduce environmental rights. ${ }^{8}$ Since then, many African countries have followed suit, introduced environmental rights into their constitutions, and

4 L Sohn "The Stockholm Declaration on the Human Environment" (1973) 14(3) Harvard International Law Journal 423-515.

5 P. Lewis et al An Introduction to Global Environmental Issues (1997)439.

6 "The Rio Declaration on Environment and Development, 1992" (2012).

7 Handle (note 2 as above).

8 F. Michael \& W. Plessis "Introduction" in M. Faure \& W. Plessis (eds.) The Balancing of Interests in Environmental Law in Africa (2012)xxix. 
introduced environmental framework and specific sectoral laws focused on addressing new challenges arising on the continent. ${ }^{9}$ The 1996 Con-stitution of South Africa and constitutions of other countries such as Botswana, ${ }^{10}$ Cameroon, ${ }^{11}$ Democratic Republic of Congo, ${ }^{12}$ and Ethiopia incorporated environmental rights to its citizens.

Coming to the Ethiopian context in particular, "There is no question that Ethiopian environmental policy has been heavily influenced by international norms, particularly by the principle of sustainable development." ${ }^{13}$ The Constitution of the 1995 Federal Democratic Republic of Ethiopia (FDRE) (hereafter "the 1995 FDRE Constitution" or "Constitution") makes several direct references to the environment and environmental rights.

This article is organized into five sections. After this introduction, section 2 examines the scope and content of environmental rights in Ethiopian law, while section 3 discusses the state of implementation of key environmental rights instruments in the country. It shows the gaps in practice concerning the robust realization and protection of environmental rights tenets. Section 4 examines the factors responsible for the poor application and implementation of environmental rights in the country, and section 5 offers recommendations on how to better realize and protect environmental rights in the country.

\section{SCOPE OF ENVIRONMENTAL RIGHTS IN ETHIOPIAN LAW}

The scope of what constitutes environmental rights may vary from one jurisdiction to another. The minimum bundle of rights that are common

9 M. Bekele “The Scope of Citizens' Environmental Rights Protection under Ethiopian Law" in M. Faure \& W. Plessis (eds.) The Balancing of Interests in Environmental Law in Africa (2012)113.

10 B. Maripe "Development and Balancing of Interests in Environmental Law: The Case of Botswana" in F. Michael \& W. Plessis (eds) The Balancing of Interests in Environmental Law in Africa (2012)63.

11 O. Fuo and S. Semie "Cameroon's Environmental Framework Law and the Balancing of Interests in Socio-Economic Development" in F Michael \& W Plessis (eds.) The Balancing of Interests in Environmental Law in Africa (2012)75.

12 K. Kennedy, Kihangi "The environmental law framework of the Democratic Republic of the Congo and the Balancing of Interests" in F. Michael \& W. Plessis (eds) The Balancing of Interests in Environmental Law in Africa (2012)95.

13 J. Krueger et al. "Environmental Permitting in Ethiopia: No Restraint on 'Unstoppable Growth?”' 1(1) Haramaya Law Review (2012)73. 
to both civil and common law legal systems are the right to live in a clean and healthy environment (also called the right to quality environment), the right to information, the right to public participation in environmental matters, and the right to access to environmental justice. ${ }^{14}$

The first right is the right to a clean and healthy environment. As indicated above, the Ethiopian Constitution guarantees "All persons have the right to live in a clean and healthy environment". ${ }^{15}$ The country's environment policy also provides for the right of every person to live in a clean and healthy environment. ${ }^{16}$ This thread of environmental right is also further entrenched on other subsidiary laws of the country. For example, the labour law proclamation ${ }^{17}$ and the civil servant's law proclamations ${ }^{18}$ include this principle in relation to the working condition of workers/employees. This principle is already included in the two pioneering international conventions. ${ }^{19}$

The second environmental right is the right to information. The idea that citizens should have the right to information about the environment is also another established right at a broader level. As an environmental right, this right helps the public to act on environmental jeopardy. It also aims at alerting decision-makers to take into account informing the public when they make decisions on environmental issues. Different instruments in Ethiopia enshrine this right too. The Constitution recognizes the right of citizens to information in general, which should also include the right to information about the environment. ${ }^{20}$ To give more examples, the environmental pollution control proclamation ${ }^{21}$ and its council of ministers regulation ${ }^{22}$ recognize this right. Under international instruments, the 1992 Helsinki Convention gives a note to this right. ${ }^{23}$

14 D. Shelton and A. Kiss Judicial Handbook of Environmental Law UNEP (2005) xix.

15 The 1995 FDRE Constitution under sec 44.

16 The 1995 Environment Policy under sec 2.3(a), hereafter the Policy.

17 Labour Law Proclamation 377 of 2003 under secs 12(4) and 92.

18 Federal Civil Servants Proclamation 515/ of 2007 under sec 48.

19 Under international instruments, Principle 1 of the Stockholm Declaration linked environmental protection to human rights norms.

20 Sec 29(2).

21 Environmental Pollution Control Proclamation 300 of 2002 under sec 19.

22 Prevention of Industrial Pollution Council of Ministers Regulations 159 of 2008 under sec 11.

23 Sec 60. 
The third one, which is access to justice, is also an important component of environmental right. There are provisions in the Ethiopian legal framework on the right to stand up for environmental rights. There are legal provisions that empower "any person" to institute a lawsuit even if a case is not in their vested interest. The Constitution says, "everyone" has the right to bring to court any justiciable matter. ${ }^{24}$ This provision is not specific to the environment, but it is indicative of the fact that "any person" can bring any justiciable matter to court. Also, there are specific provisions on the environmental laws regulating environmental rights. ${ }^{25}$ From all the legal provisions, we can conclude that there is a legal intention of liberalizing environmental consciousness and protection in Ethiopia. In addition to the State that has an inherent right, ${ }^{26}$ individuals and non-governmental organization ${ }^{27}$ have stakeholder rights on environmental issues without necessarily proving vested interest in a case. The 1998 Aarhus Convention ${ }^{28}$ is a unique international legal instrument on this strand of environmental right.

The fourth right is the right to public participation. Citizens are entitled not only to information about the environment but also to

24 Sec 37(1).

25 Environmental Pollution Control Proclamation 300 of 2002 under sec 11(1) says, "everyone" has the right to environmental standing without necessarily asserting a vested interest. Moreover, Prevention of Industrial Pollution Council of Ministers Regulations 159 of 2008 under sec 27 lay down the legal regime on the environmental standing.

26 P. Mwebaza et al. "Environmental Crimes in Ethiopia" (July 2009 Situation Report)10, available at http://globalinitiative.net/wp-content/uploads/2017/ 01/ethz-environmental-crime-ethiopia.pdf (last accessed 03 March 2017).

27 The only or one of few court cases is this: According to the rule of "any person", or "everyone", NGOs and environmentalists have the right for environmental standing, have the right too. The practicality of the rights given by the FDRE Constitution and Proclamation 300/2002 are being tested in court even though infrequently. A famous case for NGOs is Action Professionals' Association for the People (APAP) vs. Environmental Protection Authority (EPA). This was the case where APAP sued EPA for the latter's failure to stop industries (leather industries) from polluting rivers and causing suffering to residents. First APAP requested for an administrative remedy at EPA, but the latter replied it is trying its best but could not stop since there was no then an ambient environmental standard. APAP took the case to First Instance Court which ruled that EPA cannot be sued for it is not the polluter. APAPA took the case again to Federal High Court which gave similar decision: sec 11(2) of the Proclamation cannot apply to EPA since it is not polluter.

28 Convention on Access to Information, Public Participation in Decision-Making and Access to Justice in Environmental Matters (Aarhus Convention), 25 June 1998, United Nations, Treaty Series, vol. 2161. 
participate in decision making on environmental issues. The Constitution $^{29}$ already includes public participation as a right, which also should include participation in environmental issues. The policy ${ }^{30}$ and the environmental impact assessment law $^{31}$ also incorporate this right. This right is also included in international conventions. ${ }^{32}$

\section{ENVIRONIMENTAL RIGHTS IN PRACTICE}

Even though the Ethiopian Constitution, official policies of government and other subsidiary laws incorporate environmental rights into the country's legal framework, in practice these rights are myths. Besides the inefficiency and lack of regulatory instruments, ${ }^{33}$ the legal rules on environmental rights in the country are simply not enforced to the extent they can be. This area of rights is probably one of the areas of law that is the least importance to Ethiopians.

\subsection{The Right to a Clean and Healthy Environment}

Among other rights, the right to a clean and healthy environment seems to be one of the least served components of environmental rights in Ethiopia today, particularly for the community living around tanning industries. In a mixed empirical study conducted for this article, a resident who also works somewhere around a leather industry in Addis Ababa said, "In this area, gone are times when there were freshness and beauty." ${ }^{34}$ Other informants also complained of the terrible odour in their area which compelled some of their neighbours to sell their

29 Secs 43(4), 89(6), and (7).

30 Sec 4.2

31 Environmental Impact Assessment Proclamation 299 of 2002 under sec 15.

32 The Rio Declaration on Environment and Development, 1992; Convention on Access to Information, Public Participation in Decision-Making and Access to Justice in Environmental Matters (Aarhus Convention), 25 June 1998, United Nations, Treaty Series, vol. 2161 Under international instruments, among others, Principles 10 and 22 of the Rio Declaration and the 1998 Convention on Access to Information, Public Participation in Decision-Making

33 See also S Fantaye "Regulation of Industrial Effluents Causing Objectionable Odor under the Current Legal Regime of Ethiopia: The Case of Selected Industries around Addis Ababa" Unpublished BA thesis, Addis Ababa University (2006).

34 Interview with confidential community informant CI7, Addis Ababa, 3 June 2016. 
homes cheaply and abdicate the area because of the horrendous stench emanating from industrial and household effluent. Another informant added: "Some of us are numb here because of the stench". ${ }^{35}$ Indeed, most residents in Addis Ababa complain of the unmitigated stench in many parts of the city. There are musty waste dumps and effluents confronting passers-by daily as they commute from their homes to work.

The more disappointing thing is the seeming division of labour in fouling up the environment: the rich investors stink up the environment; the poor bear the medical costs and suffer the environmental consequences. The rich grow richer from the proceeds of their investments in industries; the poor grow weaker and poorer from the effects of air, land and sea as well as industrial waste pollution on their health. The poor live their entire lives surrounded by industrial waste. There is no doubt that the problems of an unhealthy and unclean environment in general and the environmental problem of industrial waste disposal, in particular, constitute a great peril in the cities of many developing countries. ${ }^{36}$ The problem is even more acute in cities like Addis Ababa which has a rapid population increase and a measure of economic growth.

However, what is the government doing to check the industries denying the right to a clean and healthy environment to residents of, say, Addis Ababa? A three-year report by the Addis Ababa Environment Protection Authority (AAEPA) shows pinpoints some measures being taken in this regard. In particular, AAEPA takes administrative and legal measures against industries violating the right to a clean and healthy environment as shown in Table 1.

Table 1 shows a high performance (particularly for the last two years) and gives the impression that the state undertook strong regulatory measures for the indicated periods. However, these measures are neither adequate nor effective. As will be shown in the section dealing with factors responsible for poor enforcement of the environmental rights, the stated number of industries upon which the measures (both administrative and legal) are taken is very small since

35 Interview with confidential community informant CI12, Addis Ababa, 12 June 2016.

36 See for example T Mpofu "Urbanization and Urban Environmental Challenges in Sub-Saharan Africa" 6(2) Research Journal of Agricultural and Environmental Management (2013)127-134. 
there are at least 20,000 industries in Addis Ababa today and most of which seem to commit continuous environmental offence. Moreover, the effectiveness of measures supposedly taken is questionable since their implementation is hampered by the intervention of state/political power holders or corruption.

Table 1. Regulatory Measures Taken by AAEP on Factories Polluting the Environment

\begin{tabular}{lccr}
\hline Year & $\begin{array}{c}\text { Planned Measure } \\
\text { (Administrative and } \\
\text { Legal) }\end{array}$ & \multicolumn{2}{c}{ Performance } \\
\cline { 3 - 4 } & 55 & Number & \% \\
\hline $2013 / 14$ & 131 & 41 & 75 \\
$2014 / 15$ & 184 & 332 & 142 \\
$2015 / 16$ & $\mathbf{3 7 0}$ & $\mathbf{5 5 9}$ & $\mathbf{1 3 2}$ \\
Total &
\end{tabular}

Source: Compiled by the Researcher from AAEP Three Years' Reports.

\subsection{Access to Justice}

Regarding enforcement of rights relating to access to justice also, there are many constraints in practice. The environmental rights are not often the subject of court proceedings as are other rights. During the fieldwork for this study, several people complained about the distress they around the leather industries where they live. I have tried to understand how much of these complaints are represented in the proceedings before a court of law or an administrative organ. The result shows that there is little evidence of practical cases in court. In my search of administrative or court cases on the industrial waste lawsuit, I also found little. Most of the complaints are not taken to the level of court proceedings. There are however several examples attesting the complaint of people to administrative organs other than the court, about their health concerns due to the noxious odour and other negative consequences of industrial waste that they suffer. Other scholars ${ }^{37}$ have also concluded from their assessment that people are not accustomed to taking their cases to court particularly when they relate to environmental issues. The reason

37 Mwebaza, et al (n 25 as above). 
for this may not be unconnected with delayed justice on environmental matters.

\subsection{The Right to Information and Public Participation}

In addition to the right to a clean and healthy environment as well as for access to justice, the other aspects of environmental rights (i.e., the right to information and the right to public participation) are similarly jeopardized. Asking informants if they have access to information about what is going on in their environment (in the case of this study particularly those living around tanning industries in Addis Ababa) is like asking the obvious. Likewise, consultation with the people whenever anything happens in their environment is similarly under constraint. The perception of people around the tanning industries on the upholding of their environmental rights is completely negative.

One of the mechanisms for effective public participation in decisionmaking is the EIA study. ${ }^{38}$ However, in practical terms, this is not being respected among private "consultants" in Addis Ababa. An expert informant indicated that as many as forty consulting private firms carry out EIA study in Addis Ababa. According to the informant, the primary objective of these consultants is to maximize profit and minimize cost. Most of them are unwilling to undertake genuine EIA studies with public participation. A key expert informant argued that the primary concern of the firms is to collect money.

Similar studies have also come up with the same result directly or indirectly showing one or more of the environmental rights of communities in Ethiopia are myths. ${ }^{39}$

\section{WHY ENVIRONMENTAL RIGHTS ARE POORLY ENFORCED IN ETHIOPIA}

Ethiopia faces several challenges in its effort to protect environmental rights. This section discusses some of the significant contributing factors

38 Environmental Impact Assessment Proclamation 299 of 2002 under sec 15.

39 D. Ruffeis et al. "Evaluation of the Environmental Policy and Impact Assessment Process in Ethiopia" 28(1) Impact Assessment and Project Appraisal (2010)29"40; D Seyoum "Assessment of Occupational Skin Diseases and Associated Factors among Tannery Workers of Selected Tanneries, Addis Ababa, Ethiopia" (2014) MA Thesis, Addis Ababa University; A Yusuf "Assessment on Corporate Social 
to the poor implementation and enforcement of environmental rights in Ethiopia.

\subsection{Lack of Capacity and Commitment for Enforcement}

The capacity to enforce regulations and the political will to do so are two of the key factors affecting the enforcement of environmental rights in the country. Whether this has real or rhetorical validity, speaking for overall government activities, the justification is correct as far as enforcement of environmental rights is concerned. In the context of enforcing environmental rights, part of the challenges relates to a lack of capacity with agencies responsible for enforcing environmental legislation and limitations in the police force in the case of "environmental crimes". ${ }^{40}$

In the first place, lack of proper and up-to-date technology is to blame. Environmental protection requires the use of up-to-date technologies, but there is a lack of environmental infrastructure in the case of Ethiopia. For example, environmental protection requires setting and implementation of emission standards which would be unique to every industrial sector. For this, adequate material infrastructure is needed to measure ambient environmental quality. Application of one or more of technology to model and monitor environmental problems and to conserve the environment is a sine qua non to environmental protection. As technology can be the cause of environmental problems, so too can it be the solution.

There is also the problem of lack of adequate and skilled number of workforce. EIA study review is a process of checking the validity of the EIA study conducted by private consulting firms. As indicated above, currently, there are about forty licensed private consulting firms that carry out EIA studies in Addis Ababa. Experts at AAEPA only do the review to check the validity of the report/study, and there are only three experts for the whole of Addis Ababa today. There is also a problem of staffing employees at AAEPA. Many key expert informants argued that EPA is an office staffed with "political offenders" such as a vice-

Responsibility Practices and Determinants: A Comparative Study Conducted in Addis Ababa Tannery and Awash Tannery" (2013) MA Thesis, Addis Ababa University; and Bekele (n 8 as above).

40 Ruffeis et al (n 36 as above). 
director who was downgraded from the post of a chief executive and another two who were fired from their previous positions. Neither of the two was said to have relevant qualifications for the work they were assigned.

Lack of adequate standards and legal framework is also another problem. Even though the 1995 FDRE Constitution, the 1997 Policy, and other regulations laws exist, they only stipulate what is to be done. A number of these instruments have no prescribed environmental quality standards. This includes standards specifying car pollution, hazardous chemical wastes and how much damages a polluter should pay for polluting the environment.

\subsection{Lack of Environmental Awareness}

The second problem responsible for poor implementation of environmental rights in Ethiopia is lack of awareness. People generally have a poor understanding of environmental rights, ${ }^{41}$ and these include environmental planners, the police, and the judges. Environmental impact assessment is not something policymakers, and practitioners would undertake on their own volition. ${ }^{42}$ Even the existing legal instruments are the result of external donors' pressure. ${ }^{43}$ Moreover, there are situations where the police deliberately whittle down the gravity of environmental offenses ${ }^{44}$ while few cases that eventually made it to trial have faced considerable impediments during trial because lawyers and judges lack the requisite training to correctly interpret environmental laws.

AAEPA has been trying to create better environmental awareness by training workers in public and private sectors on how to protect the environment. Apart from this, awareness is also being created through environmental units in schools, distribution of flyers and posters to the community, and use of media.

Unlike Table 1 which shows overated performance, Table 2 shows a low performance of awareness-raising activities done by AAEPA. The two tables show evidence of poor planning and reporting by the environmental protection agency. In any case, informants disclosed

41 Ruffeis et al (n 36 as above); Bekele (n 8)29.

42 Ruffeis et al (n 38 as above).

43 Ruffies et al (n 39 above).

44 Mwebaza et al (n 34 above) 23. 
that efforts at environmental awareness creation is fraught with challenges. People affiliated to the ruling political party are usually the ones recruited for an event since there would be a small per diem (50 Birr per day). In fact, party members are favoured from the highest official to the lowest community levels. Hence, the same people could be presented for training several times at the expense of the technical personnel of the environmental protection agencies even when the training requires prerequisite technical skills that the party memebers do not have.

Table 2. AAEPA Environmental Awareness-Raising Activities

\begin{tabular}{lrrrrrc}
\hline \multirow{2}{*}{ Year } & \multicolumn{2}{c}{ Plan } & \multicolumn{2}{c}{ Performance } & \multicolumn{2}{c}{ Per cent } \\
\cline { 2 - 7 } & Events & Participants & Events & Participants & Events & Participants \\
\hline $2013 / 14$ & 130 & 16,180 & 64 & 12,118 & 49 & 75 \\
$2015 / 16$ & 100 & 13,000 & 32 & 9,750 & 32 & 75 \\
Total & $\mathbf{2 3 0}$ & $\mathbf{2 9 , 1 8 0}$ & $\mathbf{9 6}$ & $\mathbf{2 1 , 8 6 8}$ & $\mathbf{4 2}$ & $\mathbf{7 5}$ \\
\hline
\end{tabular}

Source: Author's compilation from AAEPA Report.

According to informants at the AAEPA, there is a crisis of awareness running through different sgments of the society. For example, a construction company took a contract to build an asphalt bridge. In March 2016, a community in Addis Ababa complained that this company was polluting the environment. When the company was summoned to show whether it undertook proper EIA and public participation, it came up with a signature of 100 people as evidence. To counter that, 7000 individuals petitioned the AAEP demanding that the company stop polluting their environment. Then consultants and project advisors were called in for a fresh EIA study. This shows that even the environmental protection agencies appear to be failing to meet the expectation of the society, be it small or big.

\subsection{Delayed Justice System}

Inhabitants of the polluted environment show signs of despair because of the existing environmental justice system which is extremely slow. Many cases that proceeded to court for prosecution have not been successful concluded because of the nature of the system, which has 
no clear understanding of environmental law. This argument has already received support in the literature. ${ }^{45}$

Table 3. Handling of Complaints by AAEPA and Its Branch Offices

\begin{tabular}{lccr}
\hline Year & $\begin{array}{c}\text { Proposed Complaints for } \\
\text { Handling by AAEPA }\end{array}$ & Performance & \multicolumn{1}{c}{$\%$} \\
\hline $2013 / 14$ & 1832 & 1331 & 72.65 \\
$2014 / 15$ & 830 & 959 & 113.54 \\
$2015 / 16$ & 950 & 1712 & 180.21 \\
Total & $\mathbf{3 6 1 2}$ & $\mathbf{4 0 0 2}$ & $\mathbf{1 1 0 . 7 9}$ \\
\hline
\end{tabular}

Source: Author's Compilation based on AAEPA Report.

Table 3 also shows the inflated results of environmental complaints handled by the regulatory agency. In particular, it shows that the complaints were handled by AAEPA and not by a court or tribunal.

\subsection{Lack of Environmental Accountability}

Lack of a sense of accountability is another problem affecting the protection of environmental rights in Ethiopia. For example, if an environmental offence is reported to the EPA, which is rare, the authority will dispatch investigators, conduct all the required research, but this hardly leads to prosecution. The reasons for this could either be inadequate knowledge on the next steps to take, or neglect or even collusion. Stakeholders confirm to me that the officials lack the initiative to take institutional or personal accountability for these environmental offenses. The accountability index in the environmental protection agencies is low; hence there is no commitment in all the vital organs of the agencies to change the situation.

\subsection{Conflict between Economic Interest and Environmental Issues}

Perhaps the most crucial problem responsible for poor enforcement of environmental rights is a conflict between environmental and economic

45 See, for example, Mwebaza et al (n 41 as above). 
interest. The state actors seem to hve this curious notion that too much care for environmental protection affects economic growth; hence, regardless of what is in the law books and the official policy, they let the economy "grow" while neglecting the environment. I have collected a number of cases which prove that this is indeed true in the context of Addis Ababa.

Needless to say that an environmental impact assessment aims to protect the environment by ensuring that a project does not have a negative impact on the environment and, where this cannot be done, to minimize such impact. The environmental impact assessment law of the country says, "no person shall commence implementation of any project that requires environmental impact assessment." ${ }^{\prime 6}$ However, in the current practice of EIA in Addis Ababa, no project is known to deliver its EIA even after project completion! It has been said that sometimes when AAEPA officials round up companies for violating the EIA procedure, some government official would just give a call and force the officials to let the culprit go with the violations. ${ }^{47}$

Even more surprising, there are even some projects that skip EIA procedure altogether. The law $\mathrm{w}^{48}$ obliges "every project" to pass through an EIA procedure. However, there are organizations that run their business without any EIA permit. This problem is widespread both in government projects, such as the Addis Ababa Light Railway Project, Sub-Saharan Africa's First Light-Rail Network, as ell as in private investments. An example of a private investment involved in this abuse of procedure is the Turkish industrial zone development project. In 2009, the Turkish construction firm and industrial zone developer, Akgün Group, signed an agreement with the Ethiopian Government for the development an international industrial zone in the Oromia Regional State near Sendafa town, $35 \mathrm{~km}$ north of Addis Ababa. Akgün secured 1,000,000 $\mathrm{m}^{2}$ (100 hectares) of land from the Oromia Regional State. The total cost of the project was estimated to be US\$10 billion, and it was projected to employ one million people. ${ }^{49}$ An informant from AAEPA says of the project:

46 Environmental Pollution Control Proclamation 299 of 2002 under sec 3(1).

47 Interview with a confidential expert informant EI4, AAEPA, 20 April 2016.

48 Environmental Pollution Control Proclamation 299 of 2002 under sec 5 (1).

49 "Ethiopia: Govt Suspends Nation's Largest Turkish Industrial Zone Project" The Reporter 20 September 2014. 
Once the Turkish came ... an industrial zone around Sendafa was being created for their industries which was planned to host 800 factories. We did not know them, and they did not undergo an environmental impact assessment, and there was no public consultation either. [Officials from] Addis Ababa Water and Sewerage Authority came to our office, and they blasted us. They asked why we gave an EIA study approval for this huge project at the place where 60 per cent of potable water comes for Addis Ababa. We did not actually give an EIA approval. We did not know what was happening there. ${ }^{50}$

The uproar from both the Addis Ababa Water and Sewerage Authority and AAEPA was so strong that the Ethiopian government later suspended the multibillion-dollar Ethio-Turkish industrial zone development project because of the potential threat it posed to the Legedadi Dam and Water Treatment Plant. ${ }^{51}$ As indicated above, this is against the requirement of the law for EIA. ${ }^{52}$

Moreover, for the authorities to focus on the economic gain rather than the potential threats to the environment, sometimes, some projects that fail environmental quality tests were directly opened by an order from the authorities. Informants have mentioned some cases, but I will mention one as an example.

Two years before this last one, two industrial projects, a leather and a textile factories, were closed down for failing environmental quality tests. However, someone ordered us to open them within 24 hours of their closure. Two of the staff refused to open them, and they were removed from their job. Someone opened them because authorities insisted him. ${ }^{53}$

According to informants, the focus of government agencies is to meet their economic objectives no matter the cost to the environment. This means that authorities in charge of small and micro enterprises give license to enterprises that are not environmentally-friendly, including those which pollute the rivers by running their business on a riverside. Authorities in trade and industry also give license or tolerate

50 Interview with a confidential expert informant EI1, AAEPA, Addis Ababa, 24 April 2016.

51 Ethiopia (n 35 above).

52 Environmental Pollution Control Proclamation 299 of 2002 under sec 5.

53 Interview with a confidential expert informant EI2, AAEPA, Addis Ababa, 25 April 2016. 
operation of leather industries that are severely damaging the environment. The focus of the people in government is on the number of enterprises an agency has managed to set up in a fiscal year, or the foreign exchang to be earned from the export of leather and leather products. The conflict between the economic interest and environmental sustainability and environmental rights is not limited to Ethiopia but affects the whole of Africa. ${ }^{54}$ This is a challenge for many African countries that focus on profit maximization and short-term gains at the expense of the quality of life of their people. ${ }^{55}$

\subsection{Corruption}

Many people are of the opinion that environmental rights are affected by corruption. There is no dpubt about this. If anything, the corruption observed on environmental issues seems to mirror the trend of corruption in the country.

The most common form of corruption reported is the bribing of front-line officers who are responsible for environment-related decision making. This involves people responsible for the closure of industries for violating environmental regulations. Corruption is rife in government offices. A factory that should not be allowed to operate under any guise is left to continue to pollute the environment and violate the right to a clean environment. No matter how much the community complains, the officials would say they have given them several warnings and have threatened them with closure. But they never close them down even for a day. They could even continue to run their business like that for a decade, wrecking much havoc on the environment without being brought to book. People believe this is because the officials have received a bribes from the offending companies. It is a sign that the country's political system promotes bribery and nepotism.

\section{RECOMMENDATIONS}

Environmental rights hinged merely on legislation are empty in the absence of their implementation. Therefore, this section offers some recommendations on how to achieve effective enforcement of citizen's

54 See. for example, Ruffeis et al (n 40 above)29 and Michael \& Plessis (n 7 above)xix.

55 Ruffeis et al (n 48 as above). 
environmental rights in Ethiopia. The measures suggested include policy, legal, and political commitment of the state towards the realization of its citizens' environmental rights.

i. Consistent application of the environmental rule of law: There is a need for a consistent application of environmental law principles irrespective of status, class or economic power. As noted in this article, the lack of consistent application of environmental law, especially the tradeoff of environmental goals for economic gains is a crucial barrier to the realization of environmental rights in Ethiopia. There should be no elite class that is free to operate without limits at the expense of the environment. Any right proclaimed as legal cannot be enjoyed without the rule of law, and so are environmental rights.

ii. Reduced or tax-free "green purchase": Owners of industries often complain of high charges, including high import taxation which makes it hard for them to acquire pollution-treatment equipment. Some factories are even in the habit of threatening to shut down when accused of polluting the environment. The factory owners complain about the high cost of importing treatment technology. Their threats sometimes sound like a boast: "I will close this industry and change it to a school, and then fire thousands of employees. The industry created jobs!" a factory owner was quaoted as saying. What happened next? The industry was tolerated, and it did not yet make any significant change. Lifting or lowering import tax for treatment equipment may not answer the whole question, but it can help compliance with the regulation.

iii. Increased awareness: The key to enforcement of environmental rights is also the introduction of a higher dimension of consciousness on the part of all stakeholders. Real awareness is required about environmental rights as human rights and the attendant obligations. Lack of awareness of environmental obligations and environmental rights as human rights by all relevant parties seems to be one of the biggest roadblocks to implementation.

iv. Revise lax policies and laws: There has been much progress by way of enacting environmental laws since the 1995 FDRE 
Constitution and the 1997 Policy have been in place. However, there must be still adequate laws and standards for every aspect of environmental issue, and the existing policy and laws need to be updated since the environmental challenges are dynamic. It is heartening to know that a revision of environment policy of Ethiopia is underway, however, this must cover regulations to set environmental standards in all areas of environmental problems, which is currently lacking.

\section{CONCLUSION}

There is no doubt that Ethioians have inalienable environmental rights as enshrined in international instruments, the FDRE Constitution of 1995, and the FDRE Environment Policy of 1997. Moreover, the government of Ethiopia has formulated different proclamations, regulations and guidelines for the smooth implementation of its environmental policy. Environmental rights of the public, therefore, are not only constitutionally guaranteed but also among the guiding principles underpinning the interpretation of the FDRE Constitution as well as the designing and implementation of public policies and legislation. ${ }^{56}$ However, environmental rights have come under frail implementation. Implementation of laws and policy, especially of industrial waste in Addis Ababa, however, is not taken seriously. There is much documented evidence in this regard through research and everyday interaction with our environment, which supports this conclusion.

To address the barriers to a consistent realization, protection, and fulfilment of environmental rights in Ethiopia, the government must show the political will to mainstream environmental issues into national development goals. Environmental objectives can no longer be treated as addtions or made subservient to economic goals. Ethiopia can only truly achieve sustainable development when the rights of its citizens to a healthy and clean environment is vigorously defended and protected in the design and implementation of the country's developmental objectives. 